\title{
HISTORY AND BIOGRAPHY
}

\author{
DR. A. MORGAN CARTLEIJGE.
}

Dr. A. Morgan Cartledge, son of Rev. Abial Morgan Cartletge and Louisa (Haygood) Cartletge, was born at IVinusboro, Fairfield County, Sonth Carolina, November 24,1858 , and died of acute cardiac dilatation, complicated by a rapid pulmonary edema, at his home in Lotisville, Kentucky, May 4. 1908. The Cartledges were of Welsh origrin and the Haygools were of English cxtraction, both of sturily stock and strong individuality, imparting to their clistinguished son their decided mental capacity and "lyysical vigor.

Dr. Cartlelge's early rducation, indec.1, practically all that he received up to the time of entering medical college, was under thu tutorage of his father. This was of great aclvantage to lim in life, for his father was not only a scholar of the highest classical attainment, but liad fine qualities as a teacher. He naturally took care that his son should be well grounded in every study necessary to a professional carecr. This work of his fatleer was a labor of love, and it was doubtless the true basis of his son's professional success. Thus well equipped, when about twenty years of age, he entered the Hospital College of Medicine in Loutisville, $\mathrm{Ky}$., from which institution he gracluated with distinguished honors in 1882. After a service of one year as interne in the Louisville City Hospital loe immediately began the practice of his profession in the eity of Louisville.

In 1884 , in the very beginning of his carcer, he becane identified as a teacher of medicine, laving received the appointment of Lecturer upon Abdominal Surgery in his Alma Mater. Soon after assuming the dutics of this position he was chosen to fill the chair of Surgery made vacant ly the death of one of his former professors in the Hospital College of Medicine. He resigned this position aiter tliree or four years and accepted a position as teaclicr of Anatomy in the Kentucky School of Medicinc. This place he oceupied until isgo, when he was called to fill the clair of "The Principles and Practice of Surgery and Clinica! Surgery," in the Louisville Mledical College. which position he filled witl signal ability up to the date of lis deatlo. Ife was a staff surgeon to the City Hospital througlout his professional life, and was for many years Chief Surgeon to the Louisville, Flenderson \& St. Louis Railroad.

Farly in his career, Dr. Cartledge became prominent in medical socicty circles, becoming an active and valuable member of the leading societies in his eity, Stite and nation. He held membership in the American Medical Associntion, the Southern Surgical and Gynecological Associntion, the Kontucky State Medical Association and many others. H-Ic served as president of the Southern Surgical and Gynccological issociation in 1900 .

For quite a number of rears lue was desirous of seeing erected at Lounsville a medical college building worthy of her extended reputation as a medical teacling center for the States of the South and West, and to that end he was untiring in his effort to accomplish its erection. To him and his colleagues is due the contruction of the superb edifice of the Louisville Medical College in Louis. ville. In architectural clegance and adaptation to the purposes of its founclers it is not excelled by any similar building in the South or West.

Dr. Cartledge was a ready and powerful writer, a fluent and forceful speaker. His 
literary work, like that of his verbal lectures, was done with clear force and convincing power and upon all live professional topics he was heard with general approval. He wrote extensively for societies with which he was connected and for the medical journals, and his articles, bearing the ear-inarks of a master, will follow lim as models of perspicacity and force. He published many papers, the principal and only those mentioned in this connection having appeared in the transactions of the Southern Surgical and Gynecological Society are as follows: "The Present Status of Drainage in Surgcry;" Southern Surgical and Gynccological Transactions, 1892; "Is Operation Dennanded in All Cases of Appendicitis?-The Best Time to Operatc," 1893 ; "Hysterectomy in Acute Puerperal Scpsis," 1895 ; "Cholelithiasis, with Report of Cases," 1896; "Myoma Originating in the Muscular Coat of the Extcrnal Iliac Vein," 1899; "A Plea for the Better Appreciation of the Limitations of Our Opcrative Work," 1900; "The Time for Opcration in Appendicitis," 190r; "The Surgical Treatment of Pancreatic Cy'sts," 1902; "Sonnc Obscriations on Our Surgical Teclunique," 1906; "Some Renotc Symptoms and Effects of Cholecystitis," 1907.

In dcbatc Dr. Cartledge was no mean adversary, sustaining his contentions with a certainty born of a wide knowledge of the literaturc of the subject and an extensive personal, practical expericnce.

His name and fame, however, rested largely upon his skill as an operator. In this particular he had few equals or peers, thoroughly equipped by his knowledge of anatomical and pathological structures, a cool head, undaunted courage and a steady hand, to see him operate was a genuine pleasure and a liberal education. His success was rcmarkable-a litte short of marvelous. From the beginning of lis practice his attention was fixed upon abdoninal and pelvic surgery, and the greater part of his brilliant and successful work was in this field. Always an cnthusiastic advocate of progressive and advanced ideas and practices in modern surgery, he was cqually earnest in defensc of conservatism. Among the first, he was found contending for the radical management of appendicitis; and his operative treatment of diseases of the gall bladder places him easily among the pioneers.

He was popular as a consultant, always fair and considerate to those with whom he came in contact. On the witncss stand as an expcrt he was clear and succinct, and few of the lcgal fraternity dared to take liberty with him. The rcmarkable success aclicycd by him in his all too brief life came through his own unaided cfforts, and there arc none who deny or bcgrudge lim all that contributed to his honor and fanc as a surgeon or as a man.

Personally, Dr. Carticdge was vcry attractive, handsome of facc and figure, genial, plcasant, companionable and hearty, he made and retained fricnds whorever he wont. Always approachable, kind and considcrate, a man who did not bear malice or speak evil, he is mourned by a large circle of fricnds, patients and acquaintances from all classes of peoplc.

Dr. Cartledge was a public spirited and patriotic citizen. There wcre few subjects or undertakings of interest and importance to the public to which he was not quick to lend a willing and helping hand, and to give his counscl and support. If he had political ambition it was not manifested by any desirc to lold political or public office.

Like most men of active life, he loved healthy, out-door sports, and in the field with dog and gun his record was nothing to be ashamed of. He was particularly fond of good horses and was always the possessor of somc of the best.

His life was a busy, actirc onc, frec from enmity and bickering, he made his own way and was tolerant of others who were his rivals 
and opponents in business. Few ean recall press were highly commendatory of his power his speaking bitterly or in derogatory terms and worth in his profession and community. of others.

His deatl is keenly feit by his professional

His funeral was large and imposing, onc assoeiates and by the grateful and appreciaseldon witnessed in the eity of Louisville. The comments in the daily and professional tive public that he served so well.

Jxo. G. Cecie, M.D. 